\title{
Morphology, Growth and Reversion in a Stable L-form of Escherichia coli $\mathrm{K} 12$
}

\author{
By T. ONODA,* A. OSHIMA, S. NAKANO AND A. MATSUNO \\ Department of Biology, Faculty of Science, Shimane University, Matsue 690, Japan
}

(Received 15 April 1986; revised 16 September 1986)

\begin{abstract}
An L-form isolated from Escherichia coli $\mathrm{K} 12$ by sequential treatment with $N$-methyl- $N^{\prime}$-nitro$N$-nitrosoguanidine and lysozyme was adapted to grow in hyperosmolar liquid cultures. It was stable in the absence of antibiotic when cultured in brain heart infusion (BHI) broth containing $\mathrm{NaCl}$ and $\mathrm{CaCl}_{2}$, the optimal concentrations being $0.34 \mathrm{M}$ and $1 \mathrm{mM}$, respectively. No growth of the $\mathrm{L}$-form was observed when $\mathrm{CaCl}_{2}$ was not added to $\mathrm{BHI}$ medium containing $0.34 \mathrm{M}-\mathrm{NaCl}$. On the other hand, when $\mathrm{KCl}$ replaced $\mathrm{NaCl}$ as the osmotic stabilizer, growth of the L-form was repressed in the presence of $\mathrm{CaCl}_{2}$. Electron microscopy of the $\mathrm{L}$-form confirmed the absence of a cell wall. A revertant strain derived from the L-form grew as a stable bacillary form in BHI medium without osmotic stabilizer. The growth characteristics of the revertant strain resembled those of the parent strain. The revertant strain produced L-forms in the presence of $\mathrm{NaCl}$.
\end{abstract}

\section{INTRODUCTION}

The transformation of bacteria into L-forms is accompanied by various morphological, metabolic and antigenic changes (Hijimans, 1962; Reusch \& Panos, 1976; Hayami et al., 1979). In bacterial L-forms, the cytoplasmic membrane is the only barrier between the cell and its environment. Stable bacterial L-forms, which can grow without cell walls, are expected to differ considerably from their original bacteria in the structure and function of their plasma membrane (Gilpin et al., 1973). Most stable L-forms require the addition of osmotic stabilizers to the culture medium : salts, sugars or serum components are commonly used. $\mathrm{NaCl}$ is not only a good osmotic stabilizer for the growth of bacterial L-forms, but it also affects several physiological processes (Linker \& Wilson, 1985). Stable bacterial L-forms which have permanently lost their cell walls but multiply in liquid media (Burmeister \& Hesseltine, 1968; Young et al., 1970; Gilpin et al., 1973; Eda et al., 1976, 1979), would prove useful in studies of bacterial transport systems and physiological mechanisms of bacterial cell membranes. The present paper describes some investigations concerning growth, morphological features and reversion of a stable L-form of Escherichia coli.

\section{METHODS}

Strains. The parent strain, Escherichia coli $\mathrm{K} 12$ strain 3301, the stable L-form NC7 derived from it, and strain RNC7-1, isolated as a revertant of NC7, were used.

Induction of $L$-forms. E. coli was grown for $3 \mathrm{~h}$ on a rotary shaker $\left(250\right.$ r.p.m.) in nutrient broth at $37^{\circ} \mathrm{C}$. The cells were centrifuged, washed three times with distilled water and suspended in the same medium containing $50 \mu \mathrm{g}$ $N$-methyl- $N^{\prime}$-nitro- $N$-nitrosoguanidine $\mathrm{ml}^{-1}$. The suspension was incubated for $30 \mathrm{~min}$ at $37^{\circ} \mathrm{C}$. The cells were harvested, washed once with brain heart infusion (BHI) broth containing $0.5 \mathrm{M}$-sucrose, and suspended in $15 \mathrm{ml}$ of the same medium containing lysozyme $\left(200 \mu \mathrm{g} \mathrm{ml}^{-1}\right)$ and $\mathrm{Na}_{2}$ EDTA $(0.05 \%)$. After $60 \mathrm{~min}$ at $30^{\circ} \mathrm{C}$, the protoplasts were plated on $\mathrm{BHI}$ agar containing $0.5 \mathrm{M}$-sucrose, $1 \%(\mathrm{v} / \mathrm{v})$ horse serum, and 750 units penicillin $\mathrm{G}$ $\mathrm{ml}^{-1}$. Of the surviving three $\mathrm{L}$-form colonies, one ( $\mathrm{L}$-form NC7) was subcultured by serial transfers on BHI agar

Abbreviation: BHI, brain-heart infusion. 
containing $1 \%$ horse serum and 750 units penicillin $\mathrm{G} \mathrm{ml}^{-1}$. After 4 months of serial passage at suitable intervals, the horse serum was omitted.

Adaptation to liquid medium. Well-developed colonies of L-form NC7 were used. Agar blocks containing L-form colonies were inoculated into $\mathrm{BHI}$ medium supplemented with $3 \%(\mathrm{w} / \mathrm{v}) \mathrm{NaCl}$ as osmotic stabilizer, $5 \%(\mathrm{v} / \mathrm{v})$ horse serum, $0.5 \%$ yeast extract, $1 \mathrm{mM}-\mathrm{CaCl}_{2}$ and penicillin $\mathrm{G}\left(100\right.$ units $\left.\mathrm{ml}^{-1}\right)$. They were incubated without shaking at $32{ }^{\circ} \mathrm{C}$. Thereafter, the horse serum was omitted. Under these conditions, the $\mathrm{L}$-forms grew as separate cells without visible evidence of lysis. Identification of the strains was made by $7.5 \%(\mathrm{w} / \mathrm{v})$ polyacrylamide gel electrophoresis of cell proteins. Protein was estimated by the Lowry method.

Growth conditions. The L-forms were grown without shaking in $\mathrm{BHI}$ medium containing $2 \% \mathrm{NaCl}, 1 \mathrm{mM}-\mathrm{CaCl}_{2}$, $0.5 \%$ yeast extract and penicillin $\mathrm{G}\left(100\right.$ units $\left.\mathrm{ml}^{-1}\right)$ at $32^{\circ} \mathrm{C}$. P medium contained $\left(1^{-1}\right) 10 \mathrm{~g}$ peptone, $5 \mathrm{~g}$ yeast extract and $2 \mathrm{~g}$ glucose. The $\mathrm{pH}$ value was adjusted to $7 \cdot 1$ with $\mathrm{NaOH}$ or $\mathrm{KOH}$. Solidified medium contained $\mathrm{BHI}$ medium supplemented with $1 \%(\mathrm{w} / \mathrm{v})$ agar, $0.5 \%$ yeast extract and 100 units penicillin $\mathrm{G}$. The parent strain was grown in BHI medium. All cells were harvested in the exponential phase of growth by centrifugation $(4000 \mathrm{~g}$, $15 \mathrm{~min}$ ), washed once with $\mathrm{BHI}$ medium containing osmotic stabilizer, and inoculated into growth medium. The suspensions were incubated at $32^{\circ} \mathrm{C}$ without shaking and growth was monitored by measuring optical density at $600 \mathrm{~nm}\left(1 \mathrm{~cm}\right.$ path length). The initial $\mathrm{OD}_{600}$ was about 0.02 .

Antibiotic susceptibility tests. The minimal growth inhibitory concentration of antibiotics was determined by the tube dilution method. BHI medium was used as growth medium for the parent strain, and medium supplemented with $2 \% \mathrm{NaCl}$ and $1 \mathrm{mM}-\mathrm{CaCl}_{2}$ for the $\mathrm{L}$-form strain. Tubes containing $4 \mathrm{ml}$ medium and serial dilutions of antibiotic were inoculated with $0.1 \mathrm{ml}$ of an exponential-phase culture and incubated at $32^{\circ} \mathrm{C}$ for $48 \mathrm{~h}$. The lowest concentration of antibiotic able to inhibit growth was determined visually.

Electron microscopy. Colonies in soft agar were cut out and fixed for $1.5 \mathrm{~h}$ in $1.5 \%(\mathrm{w} / \mathrm{v})$ paraformaldehyde and $1.5 \%(\mathrm{v} / \mathrm{v})$ glutaraldehyde in $0.1 \mathrm{M}$-cacodylate buffer $(\mathrm{pH} 7.3)$ at room temperature. The prefixed specimens were washed for $30 \mathrm{~min}$ on ice in the cacodylate buffer, and fixed in $1 \%(\mathrm{w} / \mathrm{v})$ osmium tetroxide in $0 \cdot 1 \mathrm{M}$-phosphate buffer ( $\mathrm{pH} 7 \cdot 3$ ). The fixed specimens were dehydrated in a graded ethanol series, and embedded in Epoxy resin after passage through propylene oxide. Sections were cut with glass knives and mounted on Formvar-coated grids. They were stained with saturated aqueous uranyl acetate and lead citrate, and observed in a JEM 100C electron microscope.

Chemicals. Peptone, yeast extract and BHI medium were purchased from Kyokuto Pharmaceutical Industrial Co. Sucrose (RNAase free) was purchased from Nakarai Chemicals. All other reagents used were of analytical grade.

\section{RESULTS}

Growth. The L-form NC7 of E. coli $\mathrm{K} 12$ has been maintained through about 120 transfers in BHI medium containing $3 \% \mathrm{NaCl}$ and $1 \mathrm{mM}^{-\mathrm{CaCl}_{2}}$. It is stable under these conditions. The effect of medium components on growth of the L-form is shown in Table 1. Addition of $1 \mathrm{~mm}$ $\mathrm{CaCl}_{2}$ to $\mathrm{BHI}$ medium supplemented with $2 \% \mathrm{NaCl}$ markedly improved growth and allowed maintenance of the L-form through sequential transfers. Addition of $5 \%$ horse serum instead of $\mathrm{CaCl}_{2}$ gave a similar result. On the other hand, the L-form grew poorly in the medium without $\mathrm{NaCl}$, regardless of whether supplemented with $\mathrm{CaCl}_{2}$ or serum (Table 1).

In $\mathrm{BHI}$ medium supplemented with $\mathrm{NaCl}$ and $\mathrm{CaCl}_{2}$, the L-form grew exponentially with a generation time of 5-6h, and the $\mathrm{OD}_{600}$ reached a maximum within $2 \mathrm{~d}$. No growth was observed in the absence of $\mathrm{CaCl}_{2}$.

\section{Table 1. Effect of medium components on growth of the L-form}

The L-form was grown in $\mathrm{BHI}$ medium with supplements as indicated. The $\mathrm{OD}_{600}$ was measured after $48 \mathrm{~h}$ incubation. The values are means from three separate experiments, $\pm \mathrm{SD}$.

Supplement(s)

None

$\mathrm{CaCl}_{2}(1 \mathrm{~mm})$

Serum $(5 \%)$

$\mathrm{CaCl}_{2}(1 \mathrm{~mm})+\operatorname{serum}(5 \%)$

$\begin{array}{cc}\overbrace{-\mathrm{NaCl}}^{\text {Growth }\left(\mathrm{OD}_{600}\right)}+\mathrm{NaCl} \\ 0.03 \pm 0.01 & 0.03 \pm 0.01 \\ 0.03 \pm 0.02 & 0.36 \pm 0.03 \\ 0.03 \pm 0.01 & 0.15 \pm 0.01 \\ 0.04 \pm 0.02 & 0.44 \pm 0.03\end{array}$




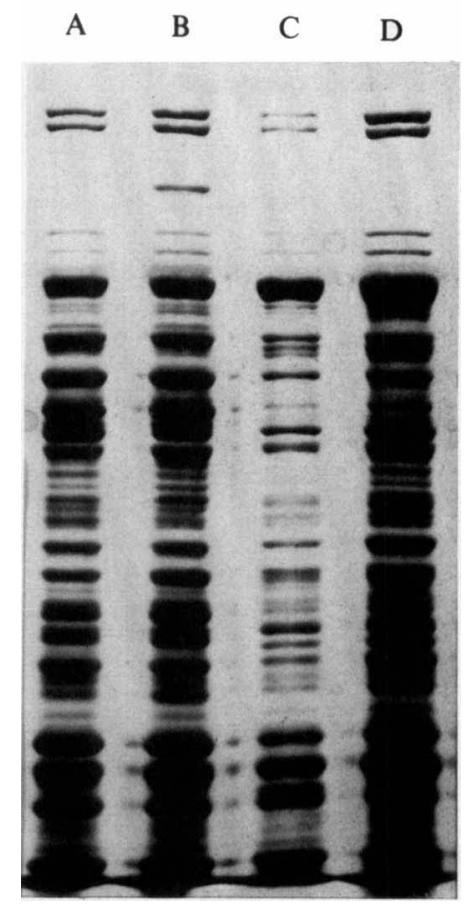

Fig. 1. SDS-polyacrylamide slab gel analysis of whole-cell extracts of the parent strain, the L-form strain and the revertant strain, all harvested in the late-exponential phase at $32{ }^{\circ} \mathrm{C}$. The gels $(7.5 \%$ SDS polyacrylamide) were stained with Coomassie Brilliant Blue $(0.124 \mathrm{mg}$ protein was applied to each lane). A, parent strain grown in unsupplemented BHI medium; B, parent strain grown in BHI medium with $2.5 \% \mathrm{NaCl}$ plus $1 \mathrm{mM}-\mathrm{CaCl}_{2} ; \mathrm{C}$, L-form strain grown in $\mathrm{BHI}$ medium with $2.5 \% \mathrm{NaCl}$ plus $1 \mathrm{mM}$ $\mathrm{CaCl}_{2} ; \mathrm{D}$, revertant strain grown in unsupplemented $\mathrm{BHI}$ medium.

\section{Table 2. Minimal inhibitory concentrations of antibiotics ( $\left.\mu \mathrm{g} \mathrm{ml}^{-1}\right)$}

The highest concentration of methicillin and penicillin $\mathrm{G}$ used in this experiment was $1000 \mu \mathrm{g} \mathrm{ml}^{-1}$; $1 \mu \mathrm{g}$ penicillin $\mathrm{ml}^{-1}$ is equivalent to 1.7 units $\mathrm{ml}^{-1}$. Data are from duplicate experiments.

\section{Antibiotic}

Chloramphenicol

Streptomycin

Tetracycline

Kanamycin

Penicillin

D-Cycloserine

Methicillin

$\begin{array}{rr}\text { Parent } & \text { L-form } \\ 5 & 2 \\ 20 & 6 \\ 4 & 1 \\ 30 & 6 \\ 1 & 1000 \\ 100 & 800 \\ 10 & 1000\end{array}$

Antibiotic susceptibility. The minimal inhibitory concentration of antibiotics known to affect protein or cell wall biosynthesis was determined to see whether the L-form differed in antibiotic susceptibility from the parent strain. Both the L-form and parent strains were sensitive to streptomycin, kanamycin, chloramphenicol and tetracycline. Penicillin, methicillin and Dcycloserine were used in these experiments, as inhibitors of cell wall biosynthesis. As expected, the L-form was resistant to these antibiotics, as compared with the parent (Table 2).

Polyacrylamide gel electrophoresis. To establish the identity of the strains and their relatedness, the electrophoretic patterns of the parent and L-form were studied. Although the gel for the parent showed some bands that were less intense than those present in the L-form patterns, there was a close similarity between the two patterns (Fig. 1), in keeping with the genetic identity of the two morphological forms. 

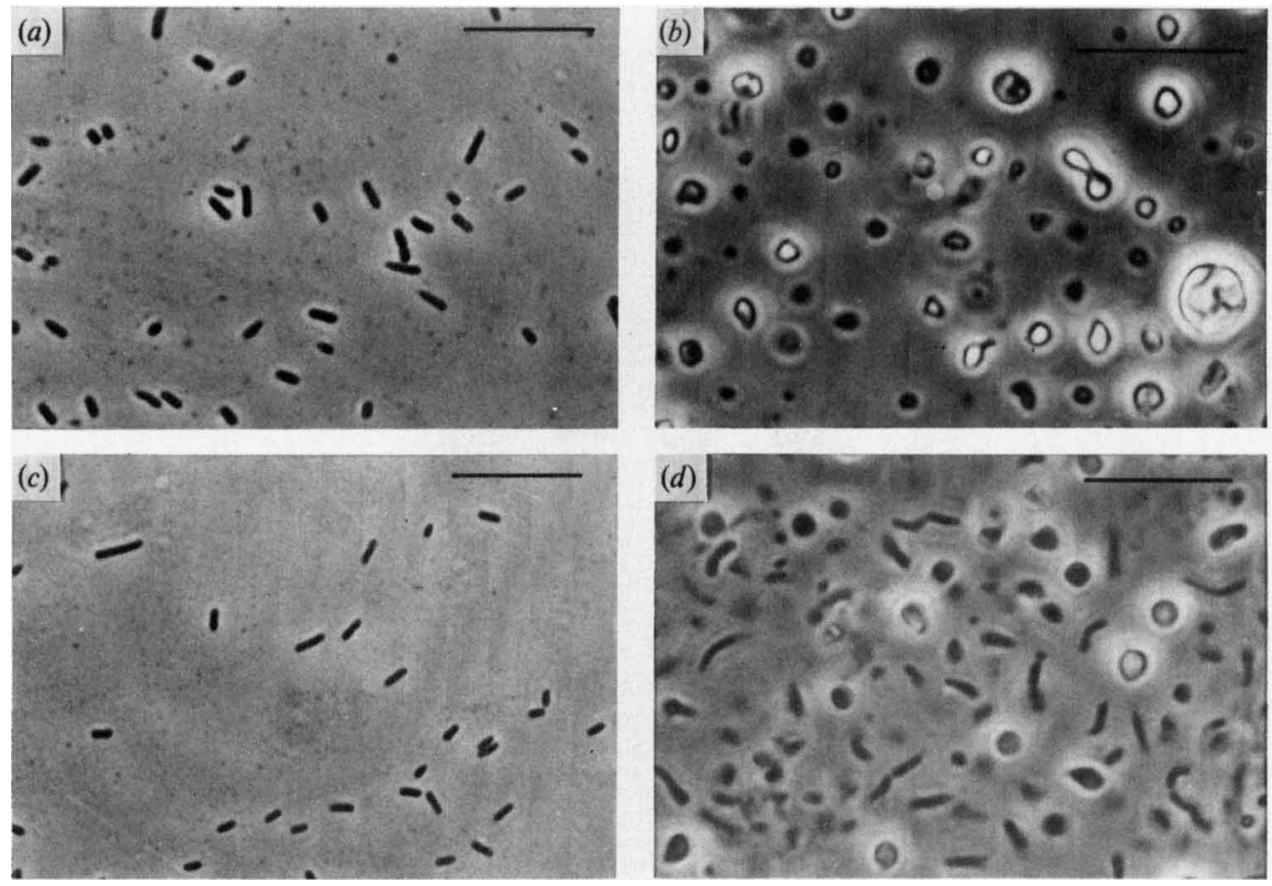

Fig. 2. Phase-contrast micrographs of the parent strain, the L-form and the revertant strain, all incubated at $32{ }^{\circ} \mathrm{C}$ without shaking. (a) The parent strain and $(c)$ the revertant strain (each $24 \mathrm{~h}$ after inoculation), in unsupplemented BHI medium; $(b)$ the L-form (48 $\mathrm{h}$ after inoculation) and $(d)$ the revertant strain ( $72 \mathrm{~h}$ after inoculation), in $\mathrm{BHI}$ medium with $2.5 \% \mathrm{NaCl}$ plus $1 \mathrm{mM}-\mathrm{CaCl}_{2} . \mathrm{Bars}, 5 \mu \mathrm{m}$.

\section{Table 3. Effects of osmotic stabilizers on growth of the L-form in BHI and P media}

The cells were grown in $\mathrm{BHI}$ and $\mathrm{P}$ media with or without $\mathrm{CaCl}_{2}$. As osmotic stabilizer, $2 \% \mathrm{KCl}, 2 \%$ $\mathrm{NaCl}$ or $0.4 \mathrm{M}$-sucrose was added. The $\mathrm{OD}_{600}$ was measured after $48 \mathrm{~h}$ incubation. The values are means from three separate experiments, \pm SD.

$\begin{array}{lccc}\begin{array}{c}\text { Osmotic } \\ \text { stabilizer }\end{array} & \begin{array}{c}\text { Addition } \\ \text { of } \mathrm{CaCl}_{2}\end{array} & \overbrace{\text { BHI medium }}^{\text {Growth }\left(\mathrm{OD}_{600}\right)} \\ \mathrm{KCl} & - & 0.47 \pm 0.02 & 0.47 \pm 0.02 \\ \mathrm{NaCl} & + & 0.30 \pm 0.02 & 0.04 \pm 0.01 \\ & - & 0.01 \pm 0.01 & 0.02 \pm 0.01 \\ \text { Sucrose } & + & 0.42 \pm 0.03 & 0.47 \pm 0.02 \\ & - & 0.31 \pm 0.02 & 0.01 \pm 0.01 \\ & + & 0.10 \pm 0.01 & 0.01 \pm 0.01\end{array}$

Morphology. Colonies of strain NC7 on BHI agar plates had the fried-egg appearance associated with L-forms. Phase-contrast micrographs of cultures of the parent and L-form are shown in Fig. 2. In liquid BHI medium supplemented with $3 \% \mathrm{NaCl}$ and $1 \mathrm{mM}-\mathrm{CaCl}_{2}$, the Lform cultures consisted mainly of spherical bodies of varying sizes. Further, many morphological forms were seen which could be related to processes of propagation: binary or asymmetric fission and a type of budding. Electron microscope examination of ultrathin sections of an L-form colony illustrated that the L-forms were bounded by a single unit membrane (Fig. 3).

Factors influencing growth of the L-form. Optimal growth of the L-form was obtained at $32{ }^{\circ} \mathrm{C}$ in the presence of $2 \% \mathrm{NaCl}$ and $1 \mathrm{mM}-\mathrm{CaCl}_{2}$ (Fig. 4). $\mathrm{MgCl}_{2}$ at various concentrations had no 

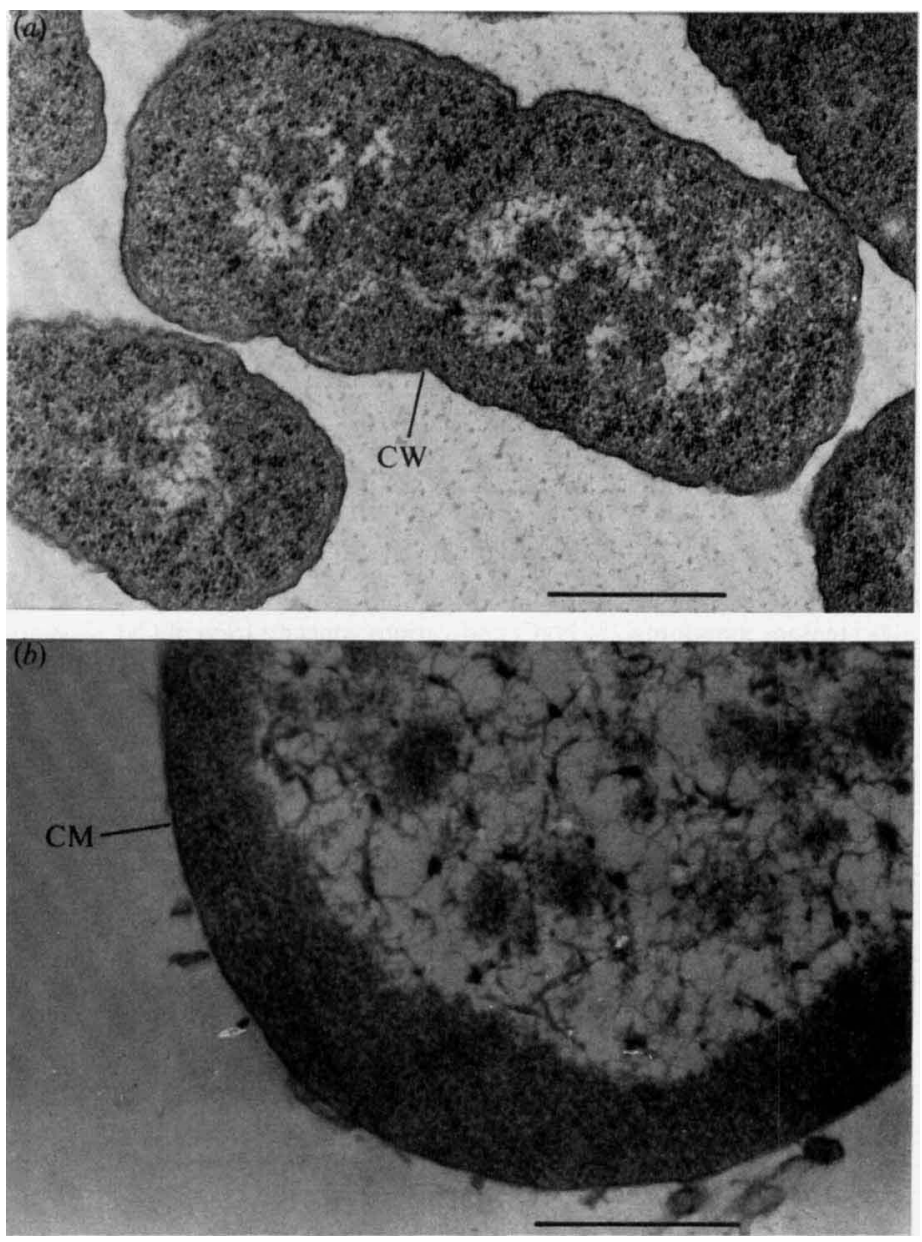

Fig. 3. Electron micrographs of cells of the parent strain and the L-form grown in BHI soft agar $(0.5 \%$ agar) medium supplemented with $2 \% \mathrm{NaCl}$. (a) The parent strain, showing the outer membrane of the cell wall. (b) The L-form: most of the cells are spherical in shape, lack a cell wall, and are surrounded by a single membrane. $\mathrm{CM}$, cytoplasmic membrane; $\mathrm{CW}$, cell wall. Bars, $0.5 \mu \mathrm{m}$.

effect on growth. Sucrose $(0.4 \mathrm{M})$ and $\mathrm{KCl}(2 \%, \mathrm{w} / \mathrm{v})$ as osmotic stabilizers, and $\mathrm{P}$ medium, were tested as substitutes for $2 \% \mathrm{NaCl}$, and $\mathrm{BHI}$ medium, respectively. The L-form grew well in $\mathrm{BHI}$ or $\mathrm{P}$ medium containing $2 \% \mathrm{KCl}$ only, but was inhibited in both the media when $\mathrm{CaCl}_{2}$ was added. Addition of $0.4 \mathrm{M}$-sucrose instead of $\mathrm{NaCl}$ to $\mathrm{P}$ medium resulted in no growth in the presence or absence of $\mathrm{CaCl}_{2}$. However, significant growth in $\mathrm{BHI}$ medium containing $0.4 \mathrm{M}$ sucrose was observed in the absence or presence of $\mathrm{CaCl}_{2}$ (Table 3). By flame photometry, $\mathrm{BHI}$ broth contained approximately $126 \mathrm{mM}-\mathrm{Na}^{+}$as $\mathrm{NaCl}$ and $52 \mathrm{mM}-\mathrm{K}^{+}$as $\mathrm{KCl}$. It appears, therefore, that the growth observed in $\mathrm{BHI}$-sucrose medium without $\mathrm{CaCl}_{2}$ was supported by the potassium ions present in BHI broth.

Reversion of the L-form. Reversion of the L-form to the bacillary form occurred frequently in BHI medium without added $\mathrm{NaCl}$ during prolonged incubation (4-5 d). The revertant strain, RNC7-1, isolated from the L-form NC7 was stably maintained in $\mathrm{BHI}$ medium without $\mathrm{NaCl}$. The colonies of strain RNC7-1 on EMB agar were black with a metallic lustre and indistinguishable from the parent strain grown under identical conditions. The morphology and 


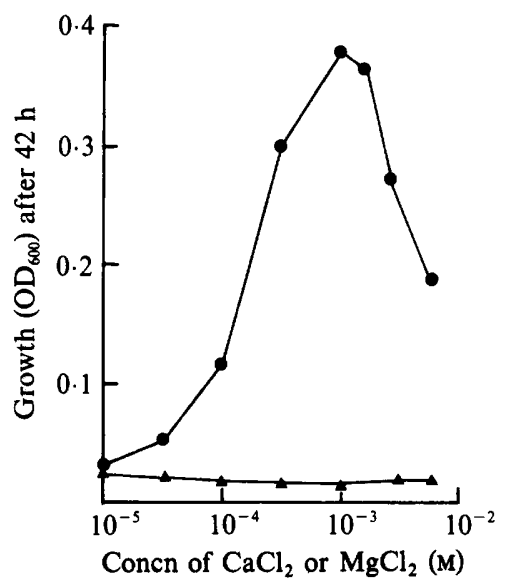

Fig. 4. Effects of the concentration of $\mathrm{CaCl}_{2}$ and $\mathrm{MgCl}_{2}$ on growth of the $\mathrm{L}$-form. The cells were grown for $42 \mathrm{~h}$ in $\mathrm{BHI}$ medium containing $2 \% \mathrm{NaCl}$ and various concentration of $\mathrm{CaCl}_{2}(\bullet)$ or $\mathrm{MgCl}_{2}(\boldsymbol{\Lambda})$.

Table 4. SDS sensitivity of the revertant strain grown in $\mathrm{BHI}$ medium with and without $\mathrm{NaCl}$ and $\mathrm{CaCl}_{2}$

The L-form, revertant and parent strains were inoculated to $\mathrm{BHI}$ medium with or without $2.5 \% \mathrm{NaCl}$, and $\mathrm{CaCl}_{2}\left(1 \mathrm{mM}\right.$ ) was added to half of the cultures. The $\mathrm{OD}_{600}$ was measured after $20 \mathrm{~h}$ (revertant and parent strains) or $48 \mathrm{~h}$ (L-form) incubation. Part of each culture was treated with SDS ( $0.05 \%)$ for $5 \mathrm{~min}$, and the $\mathrm{OD}_{600}$ immediately measured. The bacterial morphology of the cultures was observed by phase-contrast microscopy: (B), bacillary form; (L), L-form; (BL), bacillary form plus L-form. Data are from one representative experiment and are means of at least three determinations.

\begin{tabular}{|c|c|c|c|c|c|c|c|}
\hline \multirow{3}{*}{$\begin{array}{l}\text { Addition to } \\
\text { BHI medium }\end{array}$} & \multirow{3}{*}{$\begin{array}{c}\text { SDS }(0.05 \%) \\
\text { treatment }\end{array}$} & \multicolumn{6}{|c|}{ Growth $\left(\mathrm{OD}_{600}\right)$} \\
\hline & & \multicolumn{2}{|c|}{ L-form } & \multicolumn{2}{|c|}{ Revertant } & \multicolumn{2}{|c|}{ Parent } \\
\hline & & $-\mathrm{CaCl}_{2}$ & $+\mathrm{CaCl}_{2}$ & $-\mathrm{CaCl}_{2}$ & $+\mathrm{CaCl}_{2}$ & $-\mathrm{CaCl}_{2}$ & $+\mathrm{CaCl}_{2}$ \\
\hline None & - & 0.02 & 0.02 & $\begin{array}{l}0.69 \\
\text { (B) }\end{array}$ & $\begin{array}{l}0.58 \\
\text { (B) }\end{array}$ & $\begin{array}{l}2 \cdot 10 \\
\text { (B) }\end{array}$ & $\begin{array}{l}2 \cdot 10 \\
\text { (B) }\end{array}$ \\
\hline & + & ND & ND & $\begin{array}{l}0.63 \\
\text { (B) }\end{array}$ & $\begin{array}{l}0.51 \\
\text { (B) }\end{array}$ & $\begin{array}{r}2 \cdot 04 \\
\text { (B) }\end{array}$ & $\begin{array}{l}2.03 \\
\text { (B) }\end{array}$ \\
\hline $\mathrm{NaCl}$ & - & 0.02 & $\begin{array}{l}0.39 \\
(\mathrm{~L})\end{array}$ & $\begin{array}{l}0.52 \\
(\mathrm{BL})\end{array}$ & $\begin{array}{l}0.44 \\
(\mathrm{BL})\end{array}$ & $\begin{array}{l}1.04 \\
\text { (B) }\end{array}$ & $\begin{array}{l}1.02 \\
\text { (B) }\end{array}$ \\
\hline & + & $\mathrm{ND}$ & 0.01 & $\begin{array}{l}0.22 \\
\text { (B) }\end{array}$ & $\begin{array}{l}0.18 \\
\text { (B) }\end{array}$ & $\begin{array}{l}0.96 \\
\text { (B) }\end{array}$ & $\begin{array}{l}0.94 \\
\text { (B) }\end{array}$ \\
\hline
\end{tabular}

ND, Not determined.

growth characteristics of the revertant are shown in Fig. 2(c) and Table 4, respectively. The revertant exhibited normal bacillary morphology by phase-contrast microscopy and grew well in liquid medium without osmotic stabilizer when compared with the L-form, but did not grow as rapidly as the parent strain. The revertant and parent strains, maintained in BHI medium, grew with generation times of $72 \mathrm{~min}$ and $43 \mathrm{~min}$, respectively. $\mathrm{CaCl}_{2}$ had equally little effect on growth of the revertant and parent. Furthermore, the revertant was sensitive to penicillin $G$ $\left(1 \mu \mathrm{g} \mathrm{ml}^{-1}\right)$ (data not shown), as was the parent. The morphology, penicillin $\mathrm{G}$ susceptibility and growth pattern of revertant RNC7-1 were similar to those of the parent strain, although the revertant's growth rate was lower. When the revertant was transferred to BHI medium with $\mathrm{NaCl}$, it again produced the same spherical bodies as the original L-form (Fig. $2 d$ ). The first morphological change noted was the appearance of bulges which subsequently fragmented into 
distinct spheres. Production of spherical bodies was stimulated by raising the $\mathrm{NaCl}$ concentration. Addition of distilled water or SDS (0.01\%) resulted in rapid lysis of the L-form, but had no effect on the revertant and parent strains. When SDS $(0.05 \%)$ was added to the revertant culture grown in BHI medium containing $2.5 \% \mathrm{NaCl}$, the $\mathrm{OD}_{600}$ of the culture decreased (Table 4), and lysis of spherical bodies was clearly observed by phase-contrast microscopy. In addition, when the revertant (bacillary form) grown in BHI medium was treated with SDS $(0.05 \%)$, and transferred into fresh $\mathrm{BHI}$ medium with or without added $\mathrm{NaCl}$, the cells were still viable; they grew as bacillary forms in the absence of $\mathrm{NaCl}$, while in the presence of $\mathrm{NaCl}$ the culture contained a number of spherical bodies, whose production was stimulated by raising the $\mathrm{NaCl}$ concentration (data not shown). These results suggest that reversion of RNC7-1 to the 'parent' bacterium was incomplete.

\section{DISCUSSION}

The L-form of $E$. coli has been subcultured in BHI medium containing $0.5 \%$ yeast extract, $3 \%$ $\mathrm{NaCl}$ and $1 \mathrm{~mm}-\mathrm{CaCl}_{2}$ for two years. This strain is stable in the absence of penicillin $\mathrm{G}$, and does not revert under these conditions. The resistance of the L-form to penicillin, D-cycloserine and methicillin demonstrated here was anticipated, since the L-forms lack a rigid cell wall. The absence of a cell wall was confirmed by electron microscopy. Optimal growth of the L-form was obtained when $1 \mathrm{~mm}-\mathrm{CaCl}_{2}$ was added to $\mathrm{BHI}$ medium supplemented with $2 \% \mathrm{NaCl} . \mathrm{MgCl}_{2}$ had no effect on growth, whereas in the absence of $\mathrm{CaCl}_{2}$, no growth occurred in $\mathrm{BHI}$ medium containing $\mathrm{NaCl}$. Also, the $\mathrm{L}$-form did not grow unless $\mathrm{NaCl}$ was added to the medium, regardless of whether supplemented with $\mathrm{CaCl}_{2}$.

King et al. (1969) reported that a polyacrylamide gel electrophoretic method for comparison of whole-cell peptide profiles might prove of value not only in determining or confirming genetic origins of L-forms, but also in clarifying differences among L-forms of a given origin. The results obtained here indicate that the L-form possesses essentially the same patterns as those of the parent strain, thus establishing its genetic identity.

The L-form, which normally required high concentrations of $\mathrm{NaCl}$ or sucrose as osmotic stabilizer, reverted occasionally into the bacillary form during prolonged incubation in BHI medium without osmotic stabilizer. The osmotic requirement of $\mathrm{L}$-forms varies markedly with the species and strain of bacterium (Montgomerie et al., 1967). A number of bacterial L-forms can survive without osmotic stabilizer (Gilpin \& Patterson, 1976). In the present study, the revertant strain may have resulted from cells which were able to survive without osmotic stabilizer. Although $\mathrm{Mg}^{2+}$ can have an effect on reversion (from L-form to bacillary form) (Horwitz \& Casida, 1978), no such effect of $\mathrm{Mg}^{2+}$ was evident in this study. However, reversion from the bacillary to the spherical form was noted when the $\mathrm{NaCl}$ concentration in $\mathrm{BHI}$ medium was raised. This may be due to release of protein from the cell envelope. Odgers et al. (1985) reported that when exponential-phase cells of Capnocytophaga ochracea were washed with $1.0 \mathrm{M}$ $\mathrm{NaCl}$, agitated in $1.0 \mathrm{M}-\mathrm{NaCl}$ for $2 \mathrm{~h}$ at $30^{\circ} \mathrm{C}$ and exposed to lysozyme in a Tris/salts buffer, this resulted in $98 \%$ spheroplast formation with complete removal of the peptidoglycan layer. They indicated that $\mathrm{NaCl}$ washes caused the release of protein, possibly from the periplasmic space and/or from an outer periodic macromolecular monolayer.

The growth rate of the revertant strain differed markedly from that of the L-form. In addition, there were differences in the optimal growth temperatures of the parent strain $\left(37-40^{\circ} \mathrm{C}\right)$ and $\mathrm{L}$ form $\left(32^{\circ} \mathrm{C}\right)$. These may indicate that an alteration in cell metabolism has occurred in the conversion of the bacillary form to the L-form. Hayami et al. (1979) reported that staphylococcal L-forms differed from their parent bacteria in their membrane lipid composition. Our results suggest that salts such as $\mathrm{NaCl}$ or $\mathrm{KCl}$ play an important role in physiological functions, involving cation transport systems, as well as osmoregulation. It would be of value to determine the basis for the stimulatory effect of $\mathrm{CaCl}_{2}$ on growth of the $\mathrm{L}$-form in media containing $\mathrm{NaCl}$, since this may help to explain the functional mechamism involved in the $\mathrm{CaCl}_{2}$ effect. Cationtransport systems in bacteria are poorly understood. The L-form, which lacks a peptidoglycan layer, may provide an excellent tool for the study of such active transport systems. 
We wish to thank Yayoi Sakamoto for her technical assistance during the early phase of this work. We gratefully acknowledge the assistance of Hiroto Kuga in preparing the electron micrographs.

\section{REFERENCES}

Burmeister, H. R. \& Hesseltine, C. W. (1968). Induction and propagation of a Bacillus subtilis Lform in natural and synthetic media. Journal of Bacteriology 95, 1857-1861.

EDA, T., KaNDA, Y. \& KimuRA, S. (1976). Membrane structures in stable L-forms of Escherichia coli. Journal of Bacteriology 68, 1564-1567.

EdA, T., KANDA, Y., MORI, C. \& KimURA, S. (1979). Core-like and microtubular structures in a stable Lform of Escherichia coli. Microbiology and Immunology 23, 915-920.

Gilpin, R. W. \& Patterson, S. K. (1976). Adaptation of a stable L-form of Bacillus subtilis to minimal salts medium without osmotic stabilizers. Journal of Bacteriology 125, 845-849.

Gilpin, R. W., Young, F. E. \& Chatterjee, A. N. (1973). Characterization of a stable L-form of Bacillus subtilis 168 . Journal of Bacteriology 113, 486499.

Hayami, M., OKabe, A., Sasai, K., Hayashi, H. \& KANE, Y. (1979). Presence and synthesis of cholesterol in stable staphylococcal L-forms. Journal of Bacteriology 140, 859-863.

Hijimans, W. (1962). Absence of the group-specific and the cell-wall polysaccharide antigen in L-phase variants of group D streptococci. Journal of General Microbiology 28, 177-179.
HoRwITZ, A. H. \& CASIDA, L. E., JR (1978). Effects of magnesium, calcium, and serum on reversion of stable L-forms. Journal of Bacteriology 136, 565-569.

KING, J. R., Theodore, T. S. \& Cole, R. M. (1969). Genetic identification of $\mathrm{L}$-forms by polyacrylamide gel electrophoretic comparison of extracts from parent strains and their derived L forms. Journal of Bacteriology 100, 71-77.

LiNKER, C. \& WILSON, T. H. (1985). Sodium and proton transport in Mycoplasma gallisepticum. Journal of Bacteriology 163, 1250-1257.

Montgomerie, J. Z., Kalmanson, G. M. \& Guze, L. B. (1967). Effect of osmotic stabilizer on protoplast and bacterial forms of Streptococcus faecalis. Journal of Laboratory and Clinical Medicine 70, 539-553.

Reusch, V. M., JR \& Panos, C. (1976). Defective synthesis of lipid intermediates for peptidoglycan formation in a stabilized L-form of Streptococcus pyogenes. Journal of Bacteriology 126, 300-311.

Odgers, J., Dyer, J. K., Martin, E. L., Bolton, R. W. \& ANG, B. J. (1985). Induction of spheroplasts in Capnocytophaga ochracea. Journal of General Microbiology 131, 993-999.

Young, F. E., Haywood, P. \& Pollock, M. (1970). Isolation of L-forms of Bacillus subtilis which grow in liquid medium. Journal of Bacteriology 102, 867-870. 